\title{
COVID-19: neurologiniai simptomai ir encefalitas
}

\author{
A. Jasionis \\ R. Mameniškienè \\ Vilniaus universitetas, \\ Neurologijos centras
}

\begin{abstract}
Santrauka. COVID-19 pandemijos įkarštyje daugeja duomenų, kad pacientams gali pasireikšti įvairių neurologinių simptomų. Juos gali sukelti sunki bendra pacientų būklè, naujai atsiradusios ar paūmėjusios lètinès neurologinès ligos, skiriami vaistai. Taip pat pasirodo pirmieji COVID-19 encefalito atvejų aprašymai. Šiame straipsnyje aptariama informacija apie neurologinius simptomus bei galimas jų priežastis, pristatomi aprašyti encefalito atvejai, sergant COVID-19. Taip pat nagrinėjamas kitų koronavirusų sukeliamas galvos smegenų pažeidimas. Straipsnio pabaigoje diskutuojama apie galimus SARS-CoV-2 patekimo ì galvos smegenis mechanizmus.
\end{abstract}

Raktažodžiai: COVID-19 encefalitas, SARS-CoV-2, koronavirusai, encefalitas.

\section{IVADAS}

Naujasis koronavirusas (SARS-CoV-2) yra koronavirusų šeimos atstovas, žmogaus organizme pirmiausia pažeidžiantis kvėpavimo takus ir sukeliantis COVID-19, kurio pagrindiniai simptomai yra susiję su kvėpavimo sistema. Pirmą kartą nustatytas 2019 m. pabaigoje Kinijos Hubėjaus provincijoje, virusas greitai išplito po visą pasauli. Neurologams yra aktuali COVID-19 neurologinè išraiška: ar sergant pasireiškia neurologiniai simptomai, ar virusas gali sukelti galvos smegenų pažeidimą (encefalitą).

Kadangi tai - naujas virusas, mūsų žinios yra ribotos. Nors susirgusiujjų skaičius yra didelis ir nuolat didẻja, labiausiai viruso paveiktose šalyse pagrindiniai laiko ir intelektualiniai ištekliai šiuo metu pirmiausia skiriami tiesioginiam darbui su pacientais. Natūralu, kad kokybišku mokslinių duomenų kol kas stokojama: pasirodo tik atvejų aprašymai, pirmieji nedidelès apimties retrospektyviniai skerspjūvio tyrimai.

Kita vertus, tai nėra visiškai nepažịstamas virusas. Tai jau trečiasis koronavirusu šeimos atstovas, sukeliantis sunkų ūminị respiracinị sindromą (angl. severe acute respiratory syndrome, SARS): $2003 \mathrm{~m}$. pasaulis susidūrè su SARS koronavirusu (SARS-CoV), 2012 m. - Artimųu Rytu respiracinio sindromo (angl. Middle East respiratory

\section{Adresas:}

Arminas Jasionis

Vilniaus universitetas, Neurologijos centras

Santariškių g. 2, LT-09661 Vilnius

El paštas arminas.jasionis@santa.lt syndrome) koronavirusu (MERS-CoV). Dar keli koronavirusai (HCoV-229E, HCoV-OC43, HCoV-NL63 ir HCoV-HKU1) taip pat sukelia infekcijas žmogui, nors dažniausiai tai - lengvų viršutinių kvėpavimo takų infekcijų sukèlejjai. Tam tikras ịžvalgas apie galimą naujojo koronaviruso sukeliamą nervų sistemos pažeidimą galime daryti remdamiesi jo gentainiais.

\section{TIKSLAS}

Šio straipsnio tikslas apžvelgti šiuo metu prieinamą publikuotą informaciją apie neurologinius simptomus ir galvos smegenų pažeidimą, sergant COVID-19. Nepublikuoti duomenys straipsnyje nenagrinėjami.

\section{NEUROLOGINIAI SIMPTOMAI, SERGANT COVID-19}

Daugumai pacientų, sergančių COVID-19, vyrauja bendrainfekciniai (karščiavimas, silpnumas ir pan.) ir kvejpavimo sistemos simptomai (kosulys, dusulys ir pan.), rečiau - virškinimo sistemos simptomai (pykinimas, viduriavimas) [1]. Jungtinių Amerikos Valstijų ligų kontrolès ir prevencijos centras (angl. Centers for Disease Control and Prevention, CDC) pagrindiniais COVID-19 simptomais nurodo karščiavimą, kosulį ir dusulị (1 lentelè) [2].

Tyrimo, apibendrinusio 214 Uhane (Kinija) gydytų pacientų duomenis, neurologiniai simptomai pasireiškia

(C) Neurologijos seminarai, 2020. Open Access. This article is distributed under the terms of the Creative Commons Attribution 4.0 International License CC-BY 4.0 (http://creativecommons.org/licenses/by/4.0/), which permits unrestricted use, distribution, and reproduction in any medium, provided you give appropriate credit to the original author(s) and the source, provide a link to the Creative Commons license, and indicate if changes were made. 
1 lentelè. JAV ligų kontrolès ir prevencijos centro nurodomi COVID-19 simptomai [2]

\begin{tabular}{||l||}
\hline Pagrindiniai simptomai \\
\hline Kosulys \\
Oro trūkumas ar sunkumas kvėpuoti \\
\hline Papildomi simptomai \\
\hline Karščiavimas \\
Drebulys \\
Raumenų skausmas \\
Galvos skausmas \\
Gerklès perštėjimas \\
Naujai atsiradęs uoslès ar skonio sutrikimas \\
\hline Pavojingi simptomai \\
\hline Dusulys \\
Pastovus krūtinės skausmas ar spaudimas \\
Naujai atsiradusi dezorientacija ar vangumas \\
Lūpų ir veido cianozė \\
\hline
\end{tabular}

Neurologiniai simptomai paryškinti juodai.

36,4 \% sergančiujų, dažniau - sergant sunkesne ligos forma. Dažniausi simptomai: galvos svaigimas - $16,8 \%$, galvos skausmas - $13,1 \%$, raumenų skausmas $-10,7 \%$, skonio susilpnėjimas (hipogeuzija) - 5,6 \%, uoslès susilpnèjimas (hiposmija) - 5,1\%. Sąmonès sutrikimas pasireišké $7 \%$ sergančiųų [3]. Atlikus retrospektyvinę 119 nuo COVID-19 mirusių pacientu duomenų analizę, hipoksinès encefalopatijos požymiai stebėti $20 \%$ mirusių žmonių [4]. Aprašytas atvejis, kai vangumas ir priblèsusi sąmonè buvo vyraujantys COVID-19 simptomai. Tai buvo vyresnio amžiaus pacientas, sergantis lėtinėmis ligomis [5]. Galvos skausmą, kaip vieną iš COVID-19 simptomų, nurodo ir kiti Kinijoje atlikti nedidelès apimties (nuo 41 iki 138 tiriamujų) retrospektyviniai [6-8] ir vienas prospektyvinis [9] tyrimai. Galvos skausmas pasireiške 6-8 \% tiriamųjų.

58 pacientų, sergančių sunkia COVID-19 forma, apžvalgą pateikẻ dviejų Strasbūro (Prancūzija) ligoninių intensyviosios terapijos skyriai. Simptomus vertino gydytojai neurologai, ažitacija buvo stebėta $69 \%$, piramidiniai simptomai nustatyti $67 \%$ pacientų. Iš 45 išrašomų pacientų, $33 \%$ pasireiškė vykdomųjų funkcijų sutrikimo požymiai: dezorientacija, dèmesio sutrikimas, sutrikęs komandų vykdymas. Magnetinio rezonanso tomografija (MRT) atlikta 13 pacientų dèl encefalopatijos požymių: 8 tyrimuose nustatytas kontrastinès medžiagos kaupimas galvos smegenų dangaluose, 11 - hipoperfuzija abipus frontotemporalinėse srityse, 2 pacientams - smulkūs ūmios išemijos židiniai, 1 - poūmis išemijos židinys. Encefalografija atlikta 8 pacientams, jos metu stebėti nespecifiniai požymiai sulètėjimas abipus frontalinėse srityse. Septyniems pacientams atlikta juosmens punkcija, nè viename mėginyje pleocitozès nebuvo, 2 pacientams fiksuotos oligokloninès juostos (serumo atspindys), 1 - padidejusi baltymo koncentracija. SARS-CoV-2 RNR polimerazių grandininès reakcijos (PGR) būdu nenustatyta nè viename méginyje [10].

Šių tyrimų rezultatai nereiškia, kad tokiai daliai pacientų pažeidžiama nervų sistema. Galvos skausmas ir svaigimas yra nespecifiniai simptomai, galintys pasireikšti sergant bet kuria ūmine infekcine liga. Uoslès sutrikimo reikšmẻ kol kas nėra aiški. Uoslès sutrikimas būdingas ir kitoms viršutinių kvėpavimo takų infekcijoms ar sinusitui. Tačiau kai kurie duomenys rodo, kad uoslès sutrikimas gali pasireikšti dažniau. Vieno Milano (Italija) centro duomenimis, uoslès arba skonio sutrikimą nurodė 33,9 \% jų gydytų pacientų [11]. Dvylikos Europos centrų tyrimas, kuriame buvo apklausta 417 lengva ar vidutine COVID-19 forma sergančių asmenų, parodè, kad net 85,6 \% nurodè uoslès, o $88 \%$ - skonio sutrikimą, $11,8 \%$ dalyvių šie simptomai pasireiškè anksčiau nei kiti simptomai. Praejjus 8 dienoms nuo pasveikimo, uoslè buvo atsistačiusi $67,8 \%$ asmenų [12]. Pateikiama klinikinių atvejų, kai uoslès sutrikimas buvo vyraujantis [13] ar vienintelis [14] COVID-19 simptomas. Simptomas galètų būti paaiškinamas užpakalinės nosiaryklès ir kvėpuojamojo epitelio pažeidimu (neurosensorinè anosmija). Manoma, kad būtent čia virusas dauginasi, patekdamas ị žmogaus organizmą [15]. Tačiau kai kurių tyrëjų manymu, uoslès sutrikimas gali kilti dèl nosiaryklès uodžiamojo plyšio obstrukcijos (kondukcinẻ anosmija) [13].

Vis dèlto, raumenų ir galvos skausmas, naujai atsiradęs uoslès ar skonio sutrikimas CDC yra laikomi papildomais COVID-19 simptomais. Dezorientacija ir sąmonès sutrikimas kartu su dusuliu, cianoze ir skausmu ar spaudimu krūtinëje yra priskiriami prie pavojingų (reikalaujančių neatidèliotinos pagalbos) COVID-19 simptomų [2].

Daliai pacientų pasireiškia objektyvūs neurologiniai simptomai (sutrikusi sąmonė, traukuliai, židininė neurologinė simptomatika) $[3,10]$. Svarbu pažymėti, kad tai gali būti tiek tiesioginio CNS pažeidimo (encefalito), tiek sunkios bendros organizmo būklès, lemiamos karščiavimo intoksikacijos, hipoksijos ir pan., pasekmè (encefalopatija) (2 lentelè). Tiesioginis nervų sistemos pažeidimas gali būti

\section{2 lentelè. Galimos CNS pažeidimo simptomu priežastys}

\begin{tabular}{|c|c|c|}
\hline \multirow{3}{*}{$\begin{array}{l}\text { Su COVID-19 susijusi encefalopatija: } \\
\text { • hipoksija } \\
\text { • intoksikacija } \\
\text { • vidaus organų pažeidimas } \\
\text { - elektrolitų disbalansas } \\
\text { - ir pan. }\end{array}$} & \multirow[t]{3}{*}{$\begin{array}{l}\text { Su COVID-19 susijęs encefalitas: } \\
\text { • virusinis encefalitas } \\
\text { • imuninis encefalitas }\end{array}$} & $\begin{array}{l}\text { Ūminis CNS pažeidimas: } \\
\quad \text { - kraujotakos sutrikimas } \\
\text { • encefalitas (kitos kilmės) } \\
\text { • ir pan. }\end{array}$ \\
\hline & & Paūmèjusi lètinė CNS liga \\
\hline & & $\begin{array}{l}\text { Vaistų nepageidaujamas poveikis } \\
\text { Medžiagų nutraukimo simptomai }\end{array}$ \\
\hline
\end{tabular}


infekcinis (sukeliamas viruso) arba imuninis (sukeliamas imuninès sistemos atsako ị virusą) [15]. Negalima pamiršti, kad, sergant COVID-19, gali atsirasti ir gretutinè neurologinè patologija (pvz., insultas ar kitos kilmès encefalitas) arba paūmèti jau esamos lètinès neurologinès ligos. Lètinėmis neurologinėmis ligomis, remiantis 4 retrospektyvių tyrimų $(\mathrm{N}=4014)$ duomenimis, serga 8 \% COVID-19 užsikrètusių pacientų [16]. Neurologinę simptomatiką taip pat gali sukelti gydant skiriami priešvirusiniai ir kiti vaistai arba iki susirgimo vartotų vaistų ar medžiagų (pvz., alkoholio ar psichoaktyvių medžiagų) nutraukimas. Apie tai plačiau kalbama kituose šio žurnalo „Neurologijos seminarai" straipsniuose.

\section{KLINIKINIAI ATVEJAI}

Iki dabar aprašyti tik keli klinikiniai atvejai, kai buvo nustatytas SARS-CoV-2 sukeltas nervų sistemos pažeidimas.

Pirmaji koronaviruso sukelto encefalito atveji aprašè kinų autoriai iš Pekino Ditan ligoninès. 56 m. vyras, sergantis sunkia COVID-19 forma, buvo gydomas intensyviosios terapijos skyriuje priešvirusiniais vaistais ir atomizuoto interferono inhaliacijomis. Keturioliktą ligos dieną pacientui pablogėjo sąmonès būklè, atsirado veido srities trūkčiojimai ir žagsulys, stebėta vangi vyzdžių reakcija. Atlikus galvos kompiuterinę tomografiją (KT), pakitimų nestebèta. Atlikta juosmens punkcija, likvoro atsidarymo slègis buvo padidejęs. Taikant naujos kartos metagenomo sekvenavimą, likvore nustatytas SARS-CoV-2. Pacientui taikytas intensyvus priešvirusinis gydymas ir 32 ligos dieną jis perkeltas į bendrą palatą, o 39 ligos dieną geros būklès išrašytas ị namus [17].

Japonų specialistai iš Jamanašio prefektūros aprašè $24 \mathbf{m}$. vyrą, kuris 9 ligos dieną rastas namuose be sąmonės, stebètas trumpas generalizuotų toninių-kloninių traukulių priepuolis. Apžiūros metu fiksuotas sprando raumenų rigidiškumas. Galvos KT buvo be pakitimų. Likvore nustatyta limfocitinè pleocitozė - 12 ląst./ $\mu 1$. Viruso RNR nosiaryklèje nerasta, tačiau nustatyta likvore. Dèl besikartojančių traukuliu pacientas intubuotas, skirtas gydymas intaveniniu levetiracetamu. Iki tyrimo atsakymo pacientui skirta empiriné antibiotikoterapija, kortikosteroidai, toliau pacientas gydytas priešvirusiniais vaistais (favipiraviru). Atliktoje galvos smegenų MRT stebėti hiperintensiniai signalo pakitimai apie dešinijị šoninị skilveli, dešinejje temporalinejje skiltyje ir hipokampe. Publikavimo metu pacientas tebebuvo gydomas intensyviosios terapijos skyriuje [18].

Taip pat paskelbti keli encefalito atvejai, kai SARS-CoV-2 likvore nenustatytas.

Lozanos (Šveicarija) ligoninè pranešè apie du meningoencefalito atvejus pacientėms, sergančioms COVID-19. 64 m. moteriai 5 ligos dieną išsivystė psichozès reiškiniai, stebètas generalizuotų traukulių priepuolis. Meninginių simptomų nebuvo. Atlikus EEG, diagnozuota židininė epilepsinẻ būklè, kupiruota intraveniniu klonazepamu ir val- proatu. Galvos MRT - be pakitimų, likvore - limfocitinè citozė (17 ląst. $\left./ \mathrm{mm}^{3}\right)$. Viruso pacientès likvore nenustatyta. Gautas teigiamas SARS-CoV-2 atsakymas iš nosiaryklès tepinèlio. Kitai, 67 m., moteriai, kuri dẻl lengvos COVID-19 formos buvo gydoma namuose, 17 ligos dienos ryta prasidèjo stiprus galvos skausmas, po kelių valandų rasta vangi, nukritusi ant grindų. Ligoninejje stebèta dezorientacija, agresyvus elgesys su perseveracijomis, kaire hemianopsija ir sensorinis hemineglektas, meninginių simptomų nebuvo. Galvos MRT - be pakitimų, likvore nustatyta limfocitinè citozė (21 ląst./ $\mathrm{mm}^{3}$ ). SARS-CoV-2 likvore taip pat nenustatytas. Abi pacientès greitai pagerèjo, išrašytos atitinkamai po 3 ir 4 parų nuo atvykimo [19]. Apie serozinio meningito atveji, sergant COVID-19, pranešta ir iš Los Andželo (JAV) - tai 41 m. moteris, kuriai pasireiškẻ karščiavimas ir encefalopatijos reiškiniai be žymesnio kvėpavimo nepakankamumo, likvore - limfocitinè citozè (70 ląst./mm³ $)$ [20].

Kovo mėnesi aprašytas pirmas nekrotizuojančio encefalito atvejis, nustatytas Detroite (JAV): 58 m. moteris, serganti tris dienas (pasireiškė karščiavimas, kosulys, raumenų skausmas), atvežta ị prièmimo skyrių dèl dezorientacijos, sutrikusios sąmonès. Nosiaryklès tepinèlyje nustatyta SARS-CoV-2 RNR. Juosmens punkcija buvo neinformatyvi dèl trauminio kraujo komponento, herpes, varicella zoster ar Vakarų Nilo encefalito virusų nukleorūgščiu nenustatyta. Atlikus galvos KT, stebètos hipodensinės zonos abipus gumburuose. Galvos smegenų MRT parodè hemoraginius žiedu kontrastą kaupiančius židinius gumburuose, medialinėse temporalinèse ir salos srityse abipus. Pakitimai galvos smegenyse vertinti kaip ūminè nekrotizuojanti encefalopatija [21]. Ūminio demielinizuojančio encefalomielito (angl. acute disseminated encephalomyelitis, ADEM) atvejis praneštas ir iš Naujojo Džersio valstijos (JAV) - $\mathbf{4 0}$ m. moteris hospitalizuota 11 ligos dieną dèl karščiavimo, hipoksemijos. Neurologiškai pacientẻ buvo vangi, stebėta dizartrija, difuziškai sumažejusi raumenų jẻga. Likvoro sudètis buvo normali. Atliktame galvos smegenų MRT stebètos plačios pakitusio signalo zonos abiejų pusrutulių frontotemporoparietalinių sričių baltojoje medžiagoje, pamato branduoliuose, gumburuose, išorinèse kapsulèse. Kontrastinès medžiagos kaupimo nebuvo. Pakitimai vertinti kaip ADEM [22].

Kinų medikai pranešè apie mielito atvejị $\mathbf{6 6} \mathbf{m}$. vyrui, sergančiam COVID-19. Pacientui pasireiškè vangus kojų paralyžius, šlapimo ir išmatų nelaikymas. Juosmens punkcija ir nugaros smegenų MRT nebuvo atlikta. Pacientas gydytas gancikloviru, lopinaviru / ritonaviru, deksametazo$\mathrm{nu}$, intraveniniais imunoglobulinais, mekobalaminu. Koju jèga pagerèjo, vyras nukreiptas reabilitacijai [23].

\section{PATOLOGIJOS ATVEJAI}

Floridos universiteto Patologijos departamento tyrejai paskelbė atvejo aprašymą, kai SARS-CoV-2 dalelès rastos nuo COVID-19 mirusio paciento smegenyse. 74 m. vyras, sergantis Parkinsono liga, gydytas ligoninèje dèl 
COVID-19, jam pasireiške karščiavimas, pneumonija, kvėpavimo nepakankamumas, fliuktuojanti sąmonės būklè. Vienuoliktą ligos dieną pacientas mirè. Patologinio tyrimo metu kaktinių skilčių pjūviuose transmisiniu elektroniniu mikroskopu nustatyta 90-110 nm skersmens viruso dalelių neuronų kūnų vakuolėse ir kraujagyslių endotelio ląstelèse [24].

\section{KITŲ KORONAVIRUSŲ SUKELIAMAS NERVŲ SISTEMOS PAŽEIDIMAS}

Sunkaus ūminio respiracinio sindromo (SARS) virusas (SARS-CoV), atsiradęs Kinijos Guangdongo provincijoje, pasaulyje išplito $2003 \mathrm{~m}$. Nustatyta daugiau kaip 8000 atvejų. Mirštamumas siekė $10 \%$ [25]. Sergant SARS, vyrauja sunkus kvėpavimo sistemos pažeidimas. Aprašyti atvejai, kai viruso RNR nustatyta likvore [26]. Patologinio tyrimo metu viruso genomo fragmentų rasta galvos smegenų audinyje [27], kiti tyrëjai SARS-CoV smegenu audinyje nustatė taikydami elektroninę mikroskopiją [28].

Artimujų Rytų respiracinio sindromo (MERS) protrūkis (sukeliamas MERS-CoV) prasidejo $2012 \mathrm{~m}$. Saudo Arabijoje. Iš viso užsikrètė apie 2500 žmonių. Mirštamumas buvo labai didelis - siekẻ $35 \%$, kai kuriuose centruose - iki $60 \%$. Daliai pacientų greta vyraujančio kvèpavimo nepakankamumo pasireiške ir neurologiniai simptomai: galvos skausmas - $12,9 \%$, dezorientacija $-25,7 \%$, traukuliai - 8,6\% [29].

Kiti žmogaus koronavirusai (HCoV) dažniausiai sukelia sezoninị peršalimą ir neurologiniai simptomai nepasireiškia. Kita vertus, $\mathrm{HCoV}$ yra neurotropiški. Kvebeko universitete tirti autopsijų galvos smegenų mėginiai. Taikant PGR, $44 \%$ mėginių rasta sekų, atitinkančių HCoV-229E, o 23 \% - atitinkančių HCoV-OC43 RNR sekas. Išsėtine skleroze sirgusiųjų smegenų audiniuose HCoV buvo nustatyti dažniau nei kontroliniuose audiniuose [30]. Spejjama, kad HCoV gali latentiškai infekuoti neuronus. Peles infekavus kitais koronavirusais (pelių hepatito virusu, angl. murine hepatitis virus (MHV)), panašu, kad imuninè sistema greitai sustabdo viruso replikaciją smegenyse, tačiau viruso antigenai ir nukleorūgštys smegenų audinyje gali persistuoti ilgai [31]. HCoV taip pat siejami su vaikų encefalitais. Kinų tyrejjai nustatė IgM klasės antikūnų prieš žmogaus koronavirusą (anti-HCoV) $12 \%$ (22) vaiku, gydomų ligoninėje dèl encefalito. Vertinta, kad encefalito sukẻlëjas yra žmogaus koronavirusas. Dažniausi šių pacientų simptomai buvo karščiavimas $81,8 \%$, galvos skausmas $-45,5 \%$ ir vėmimas $-36,4 \%$. Traukuliai pasireiškè 22,7 \% vaikų. Sprando raumenų rigidiškumas fiksuotas $31,8 \%$ pacientų. Likvore pleocitozė nustatyta $45,5 \%$, padidejusi baltymo koncentracija $39,4 \%$ pacientų. Neurovizualiniai tyrimai atlikti 16 koronavirusiniu encefalitu sergančių vaikų, $50 \%$ rasti pakitimai periventrikuliariai, temporalinėse skiltyse ir gumbure bei pamato branduoliuose. Visi vaikai visiškai pasveiko
[32]. Kolorado valstijoje (JAV) iš 1683 vaikų, sirgusių viršutinių kvėpavimo takų infekcija, tepinėlių koronavirusai nustatyti 84 pacientų mėginiuose. 3 (4,6 \%) iš jų pasireiškè meningoencefalitas [33]. Aprašyti atvejai, kai HCoV-OC43 sukèlè mirtinus encefalitus imunosupresuotiems vaikams: kūdikiui su igimtu imunodeficitu [34] ir vaikui, kuriam taikyta chemoterapija dèl ūminès limfoblastinès leukemijos [35]. Taip pat pranešama apie ūminio diseminuoto encefalomielito (ADEM) atvejus vaikams, persirgusiems HCoV-OC43 infekcija [36].

\section{GALIMI KORONAVIRUSINIO ENCEFALITO MECHANIZMAI}

Virusai yra dažniausi encefalitų sukèlëjai, tačiau kiekvieno viruso neuroinvazinès galimybės labai skiriasi. Encefalitą dažniausiai sukelia: 1) arbovirusai, platinami erkių ir uodų (pvz., erkinio encefalito ar japoniškojo encefalito virusai), 2) herpes virusai (pvz., herpes simpex, varicella zoster ir kiti), 3) enterovirusai, kurie plinta fekaliniu-oraliniu keliu ir nervų sistema pasiekia iš žarnyno (pvz., poliovirusai, Koksaki virusai); 4) kiti virusai, dažniausiai sukeliantys vaikų virusines infekcijas (pvz., tymus, epidemini parotitą ar raudonukę), šie virusai antrinị encefalitą sukelia retai [37]. Viršutinių kvėpavimo takų virusai, pavyzdžiui, gripo virusas, nervų sistemą pažeidžia labai retai [38]. Virusai galvos smegenis gali pasiekti keliaudami nervų kamienais (pvz., trišakiu nervu, uoslès stormeniu, klajokliu nervu ir pan.) arba hematogeniniu keliu - infekuodami kraujagyslių endotelio ląsteles ir taip pereidami hematoencefalinį barjerą [39]. Kai kurie virusai, pavyzdžiui, žmogaus imunodeficito virusas, hematoencefalinị barjerą gali pereiti būdami imuninių ląstelių - monocitų viduje (Trojos arklio hipotezè) [40].

SARS-CoV-2 i organizmo ląsteles patenka per angiotenziną konvertuojantị fermentą (ACE2), kuris labiausiai ekspresuojamas kvėpavimo taku epitelyje, plaučiuose, žarnyne, kraujagyslių endotelyje, mažiau - kituose audiniuose. Manoma, kad smegenis SARS-CoV2 galètų pasiekti tiek hematogeniniu keliu per smegenų kraujagyslių endoteli, tiek retrogradiškai plisdamas neuronais iš uoslès epitelio [25]. Toks neuroinvazijos būdas įrodytas kitiems koronavirusams. Amerikiečiu mikrobiologai Ajovos universitete transgeninėms pelèms, ekspresuojančioms žmogaus ACE2, nosiaryklejje inokuliavo SARS-CoV ir nustatè, kad virusas keliauja uoslès stormeniu (bulbus olfactorius) ir plačiai išplinta įvairiose pelių smegenų srityse, žūti lemia smegenų kamieno pažeidimas [41]. Panašius duomenis gavo Kvebeko universiteto tyrèjai, infekavę peles HCoV-OC43 [42]. Po chirurginès bulbus olfactorius abliacijos pelèms, kurioms nosiaryklejje inokuliuotas $\mathrm{MHV}$, viruso plitimo ipsilateralinèje pusèje nebuvo stebèta [43]. Pasak kai kurių mokslininkų, taip gali plisti ir SARS-CoV-2, turint omenyje, kad anosmija yra dažnas ir ankstyvas COVID-19 simptomas [15]. 
Taip pat turima eksperimentinių tyrimų duomenų, kad kiti koronavirusai (HCoV-229E, HCoV-OC43 ir SARS-CoV) gali infekuoti monocitus ir taip pereiti hematoencefalinị barjerą, tai galètų būti ir vienas SARS-CoV-2 invazijos mechanizmų [25].

\section{GYDYMAS}

Kol kas nėra žinoma, kaip dažnai, sergant COVID-19, pasireiškia tiesioginis nervų sistemos pažeidimas, kadangi pasirodo tik pirmieji atvejų aprašymai. Taip pat nėra žinoma, ar vyrauja tiesioginis viruso sukeliamas pažeidimas, ar imuninès sistemos atsakas ị virusą. Virusiniam encefalitui gydyti veiksmingiausi yra priešvirusiniai vaistai. Nors bandomi ịvairūs priešvirusiniai ir kitokie eksperimentiniai vaistai, šiuo metu nėra nė vieno patvirtinto efektyvaus vaisto COVID-19 gydyti. Pacientams, sergantiems encefalitu, greta taikomo COVID-19 gydymo galètų būti skiriamas simptominis gydymas: smegenų edemą mažinantys vaistai, priešuždegiminiai vaistai ir pan. (gydymas skiriamas virusiniam encefalitui gydyti). Imuninès kilmès komplikacijoms gydyti teoriškai galètų būti efektyvūs intraveninis imunoglobulinas ar plazmaferezès. Atkreipiamas dėmesys, kad intraveniniai imunoglobulinai yra susije su padidejusia tromboembolinių komplikacijų rizika. Dèl kortikosteroidų skyrimo diskutuojama, kadangi yra duomenų, kad jie gali slopinti viruso pašalinimą iš ląstelių [44].

\section{DISKUSIJA}

Daugejjant COVID-19 sergančių pacientų, ryškèja ir neurologinis šios ligos vaizdas. Neurologiniai simptomai gali pasireikšti daliai pacientų, ypač sergančių sunkiau. Galvos skausmas ir raumenų skausmas yra nespecifiniai COVID-19 simptomai. Uoslès ir skonio sutrikimas, nors ir nespecifinis, turimų tyrimų duomenimis, pasireiškia dažnai ir gali būti vienas pirmųjų ligos simptomų. Vyresnio amžiaus pacientams, sergantiems lètinėmis ligomis, vangumas ir sąmonès sutrikimas retai gali būti net vyraujantis COVID-19 simptomas.

Neurologinè simptomatika, sergant COVID-19, gali atsirasti dèl sunkios bendros būklès: karščiavimo, intoksikacijos, hipoksijos, kitų organų pažeidimo (tai vadintume encefalopatija) ir dèl tiesioginio nervų sistemos pažeidimo (encefalito), kuris gali būti infekcinis (sukeltas viruso) ar neinfekcinis (sukeltas imuninès sistemos atsako). Neurologinè simptomatika pacientui, sergančiam COVID-19, gali atsirasti ir dèl kito ūminio nervų sistemos pažeidimo. Sunkiai sergančius pacientus gali ištikti galvos smegenų infarktas ar intrakranijinė hemoragija. Kita vertus, dalis pacientų (ypač sergančių nesunkia COVID-19 forma) susidurs ir su kitais infekciniais sukèlejjais. Net ir atsiradus meningito / encefalito simptomatikai, turime pagalvoti apie kitas neuroinfekcijas: bakteri- nius meningitus, erkinị meningoencefalitą, herpetinị encefalitą ir pan.

Pacientams, gydomiems priešvirusiniais ar imuninę sistemą veikiančiais vaistais, gali pasireikšti nepageidaujami reiškiniai. Daliai pacientų gali paūmèti lètinès neurologinès ligos.

Kol kas duomenų apie COVID-19 tiesiogiai sukeliamą encefalitą nėra gausu. Pateikti du atvejai, kai pacientui su encefalito simptomatika SARS-CoV-2 RNR nustatyta likvore. Aprašyta dar keli atvejai, kai, sergant COVID-19, išsivystė ūminis encefalitas ar mielitas, tačiau SARS-CoV-2 likvore nebuvo bandyta nustatyti arba nustatyti nepavyko. Taip pat pranešta apie pirmuosius imuninius nervų sistemos pažeidimus, sergant COVID-19. Vienas reikšmingiausių atvejų - patologijos tyrimas iš Floridos, kai virusas elektronine mikroskopija tiesiogiai nustatytas nuo COVID-19 mirusio žmogaus smegenyse.

Ankstesnių koronavirusų protrūkių (SARS ir MERS) metu sergantiesiems pasireikšdavo neurologinè simptomatika, viruso nukleorūgštys aptiktos likvore ir mirusių asmenų smegenų audinyje. Kiti koronavirusų šeimos atstovai neretai sukelia encefalitus normalios ir sutrikusios imuninès sistemos vaikams. Iš eksperimentinių tyrimų su laboratoriniais gyvūnais duomenų galime manyti, kad koronavirusai smegenis gali pasiekti net trimis mechanizmais: 1) hematogeniniu keliu infekuodami smegenų kraujagyslių endotelio ląsteles; 2) retrogradiniu būdu keliaudami uoslès stormeniu iš kvėpuojamojo epitelio (ir galbūt trišakiu nervu iš nosiaryklès); 3) „apgaudami“ imuninę sistemą, kirsti hematoencefalinį barjerą monocitų viduje. Taigi šiuo metu turime pagrindo manyti, kad encefalitas yra galima COVID-19 komplikacija. Floridos patologijos atvejo aprašyme viruso dalelių rasta galvos smegenų kraujagyslių endotelio ląstelèse. Tai iš esmès patvirtina pirmajị (hematogenini) plitimo būdą. Uoslès pažeidimas, sergant COVID-19, neleidžia atmesti antrojo (retrogradinio neuroninio) plitimo būdo, nors patikimesnių duomenų su žmonėmis nėra. Ar SARS-CoV-2 gali naudotis Trojos arkliu - monocitais ir smegenis pasiekti apgaudamas imuninę sistemą, kol kas nežinome, bet yra duomenų, kad taip elgiasi kiti koronavirusų šeimos atstovai.

\section{REKOMENDACIJOS}

Vyresnio amžiaus pacientams, sergantiems lètinėmis ligomis, pasireiškus vangumui ar sutrikus sąmonei, tikslingas ištyrimas dèl COVID-19.

Pacientams, sergantiems COVID-19, pablogejjus sąmonės būklei ar atsiradus židininei simptomatikai, indikuotina skubi galvos KT ir (ar) juosmens punkcija, siekiant atmesti galvos smegenų kraujotakos sutrikimą ar neuroinfekciją.

Pacientams su meningito / encefalito simptomatika tikslinga yra juosmens punkcija, SARS-CoV-2 RNR nustatymas likvore, ištyrimas dẻl kitų galimų (ir ypač turinčiu efektyvų gydymą) neuroinfekcijos sukèlëjų. 


\section{Literatūra}

1. Guan WJ, Ni ZY, Hu Y, Liang WH, Ou CQ, He JX, et al. Clinical characteristics of coronavirus disease 2019 in China. N Engl J Med 2020; 382(18): 1708-20. https://doi.org/ 10.1056/NEJMoa2002032

2. Centers for Disease Control and Prevention. Coronavirus disease 2019 (COVID-19). Available from: https://www.cdc.gov/ coronavirus/2019-ncov/symptoms-testing/symptoms.html

3. Mao L, Jin H, Wang M, Hu Y, Chen S, He Q, et al. Neurologic manifestations of hospitalized patients with coronavirus disease 2019 in Wuhan, China. JAMA Neurol 2020; 77(6): 683-90. https://doi.org/10.1001/jamaneurol. 2020.1127

4. Chen T, Wu D, Chen H, Yan W, Yang D, Chen G, et al. Clinical characteristics of 113 deceased patients with coronavirus disease 2019: retrospective study. BMJ 2020; 368: m1091. https://doi.org/10.1136/bmj.m1091

5. Filatov A, Sharma P, Hindi F, et al. Neurological complications of coronavirus disease (COVID-19): encephalopathy. Cureus 2020; 12(3): e7352. https://doi.org/10.7759/ cureus. 7352

6. Huang C, Wang Y, Li X, Ren L, Zhao J, Hu Y, et al. Clinical features of patients infected with 2019 novel coronavirus in Wuhan, China. Lancet 2020; 395: 497-506. https://doi.org/ 10.1016/S0140-6736(20)30183-5

7. Yang X, Yu Y, Xu J, Shu H, Xia J, Liu H, et al. Clinical course and outcomes of critically ill patients with SARS-CoV-2 pneumonia in Wuhan, China: a single-centered, retrospective, observational study. Lancet Respir Med 2020; 8: 475-81. https://doi.org/10.1016/S22132600(20)30079-5

8. Wang D, Hu B, Hu C, Zhu F, Liu X, Zhang J, et al. Clinical characteristics of 138 hospitalized patients with 2019 novel coronavirus-infected pneumonia in Wuhan, China. JAMA 2020; 323(11): 1061-9. https://doi.org/10.1001/jama. 2020.1585

9. Chen N, Zhou M, Dong X, Qu J, Gong F, Han Y, et al. Epidemiological and clinical characteristics of 99 cases of 2019 novel coronavirus pneumonia in Wuhan, China: a descriptive study. Lancet 2020; 395: 507-13. https://doi.org/10.1016/ S0140-6736(20)30211-7

10. Helms J, Kremer S, Merdji H, Clere-Jehl R, Schenck M, Kummerlen C, et al. Neurologic features in severe SARS-CoV-2 infection. N Engl J Med 2020; 382: 2268-70. https://doi.org/10.1056/NEJMc2008597

11. Giacomelli A, Pezzati L, Conti F, Bernacchia D, Siano M, Oreni L, et al. Self-reported olfactory and taste disorders in SARS-CoV-2 patients: a cross-sectional study. Clin Infect Dis 2020; ciaa330. https://doi.org/10.1093/cid/ciaa330

12. Lechien JR, Chiesa-Estomba CM, De Siati DR, Horoi M, Le Bon SD, Rodriguez A, et al. Olfactory and gustatory dysfunctions as a clinical presentation of mild-to-moderate forms of the coronavirus disease (COVID-19): a multicenter European study. Eur Arch Otorhinolaryngol 2020; 1-11. https://doi.org/10.1007/s00405-020-05965-1

13. Eliezer M, Hautefort C, Hamel AL, Verillaud B, Herman P, Houdart E, Eloit C, et al. Sudden and complete olfactory loss function as a possible symptom of COVID-19. JAMA Otolaryngol Head Neck Surg 2020; https://doi.org/10.1001/ jamaoto.2020.0832

14. Gane SB, Kelly C, Hopkins C. Isolated sudden onset anosmia in COVID-19 infection. A novel syndrome? Rhinology 2020.
15. Wu Y, Xu X, Chen Z, Duan J, Hashimoto K, Yang L, Liu C, et al. Nervous system involvement after infection with COVID-19 and other coronaviruses. Brain Behav Immun 2020; pii: S0889-1591(20)30357-3. https://doi.org/10.1016/ j.bbi.2020.03.031

16. Herman C, Mayer K, Sarwal A. Scoping review of prevalence of neurologic comorbidities in patients hospitalized for COVID-19. Neurology 2020; pii: 10.1212/ WNL.0000000000009673. https://doi.org/10.1212/ WNL.0000000000009673

17. Xiang P, Xu XM, Gao LL, Wang HZ, Xiong HF, Li RH. First case of 2019 novel coronavirus disease with encephalitis. ChinaXiv 2020; T202003: 00015.

18. Moriguchi T, Harii N, Goto J, Harada D, Sugawara H, Takamino J, et al. A first case of meningitis/encephalitis associated with SARS-Coronavirus-2. Int J Infect Dis 2020; 94: 55-8. https://doi.org/10.1016/j.ijid.2020.03.062

19. Bernard-Valnet R, Pizzarotti B, Anichini A, Demars Y, Russo E, Schmidhauser M, et al. Two patients with acute meningo-encephalitis concomitant to SARS-CoV-2 infection. medRxiv 2020.04.17.20060251. https://doi.org/ 10.1101/2020.04.17.20060251

20. Duong L, Xu P, Liu A. Meningoencephalitis without respiratory failure in a young female patient with COVID-19 infection in Downtown Los Angeles, early April 2020. Brain Behav Immun 2020; pii: S0889-1591(20)30509-2. https://doi.org/10.1016/j.bbi.2020.04.024

21. Poyiadji N, Shahin G, Noujaim D, Stone M, Patel S, Griffith B. COVID-19-associated acute hemorrhagic necrotizing encephalopathy: CT and MRI features. Radiology 2020; 2020: 201187. https://doi.org/10.1148/radiol.2020201187

22. Zhang T, Rodricks MB, Hirsh E. COVID-19-associated acute disseminated encephalomyelitis: a case report. medRxiv 2020.04.16.20068148. https://doi.org/10.1101/ 2020.04.16.20068148

23. Zhao K, Huang J, Dai D, Feng Y, Liu L, Shuke Nie S. Acute myelitis after SARS-CoV-2 infection: a case report. medRxiv 2020.03.16.20035105. https://doi.org/10.1101/ 2020.03.16.20035105

24. Paniz-Mondolfi A, Bryce C, Grimes Z, Gordon RE, Reidy J, Lednicky J, et al. central nervous system involvement by severe acute respiratory syndrome coronavirus -2 (SARS-CoV-2). J Med Virol 2020; 92(7): 699-702. https://doi.org/10.1002/jmv.25915

25. Desforges M, Le Coupanec A, Dubeau P, Bourgouin A, Lajoie L, Dubé M, et al. Human coronaviruses and other respiratory viruses: underestimated opportunistic pathogens of the central nervous system? Viruses 2019; 12(1): 14 . https://doi.org/10.3390/v12010014

26. Lau KK, Yu WC, Chu CM, Lau ST, Sheng B, Yuen KY. Possible central nervous system infection by SARS coronavirus. Emerg Infect Dis 2004; 10(2): 342-4. https://doi.org/ 10.3201/eid1002.030638

27. Gu J, Gong E, Zhang B, Zheng J, Gao Z, Zhong Y, et al. Multiple organ infection and the pathogenesis of SARS. J Exp Med 2005; 202(3): 415-24. https://doi.org/10.1084/ jem. 20050828

28. Xu J, Zhong S, Liu J, Li L, Li Y, Wu X, et al. Detection of severe acute respiratory syndrome coronavirus in the brain: potential role of the chemokine Mig in pathogenesis. Clin Infect Dis 2005; 41(8): 1089-96. https://doi.org/10.1086/444461

29. Saad M, Omrani AS, Baig K, Bahloul A, Elzein F, Matin MA, et al. Clinical aspects and outcomes of 70 patients with Middle East respiratory syndrome coronavirus infec- 
tion: a single-center experience in Saudi Arabia. Int J Infect Dis 2014; 29: 301-6. https://doi.org/10.1016/ j.ijid.2014.09.003

30. Arbour N, Day R, Newcombe J, Talbot PJ. Neuroinvasion by human respiratory coronaviruses. J Virol 2000; 74(19): 8913-21. https://doi.org/10.1128/JVI.74.19. 8913-8921.2000

31. Bergmann CC, Lane TE, Stohlman SA. Coronavirus infection of the central nervous system: host-virus stand-off. Nat Rev Microbiol 2006; 4(2): 121-32. https://doi.org/10.1038/ nrmicro1343

32. Li Y, Li H, Fan R, Wen B, Zhang J, Cao X, et al. Coronavirus infections in the central nervous system and respiratory tract show distinct features in hospitalized children. Intervirology 2016; 59(3): 163-9. https://doi.org/10.1159/000453066

33. Dominguez SR, Robinson CC, Holmes KV. Detection of four human coronaviruses in respiratory infections in children: a one-year study in Colorado. J Med Virol 2009; 81(9): 1597-604. https://doi.org/10.1002/jmv.21541

34. Morfopoulou S, Brown JR, Davies EG, Anderson G, Virasami A, Qasim W, et al. Human coronavirus OC43 associated with fatal encephalitis. N Engl J Med 2016; 375(5): 497-8. https://doi.org/10.1056/NEJMc1509458

35. Nilsson A, Edner N, Albert J, Ternhag A. Fatal encephalitis associated with coronavirus OC43 in an immunocompromised child. Infect Dis (Lond) 2020; 52(6): 419-22. https://doi.org/10.1080/23744235.2020.1729403

36. Yeh EA, Collins A, Cohen ME, Duffner PK, Faden H. Detection of coronavirus in the central nervous system of a child with acute disseminated encephalomyelitis. Pediatrics 2004; 113(1 Pt 1): e73-6. https://doi.org/10.1542/peds.113.1.e73

37. Talbot PJ, Desforges M, Brison E, Jacomy H. Coronaviruses as encephalitis-inducing infectious agents. In: Tkachev S, ed. Non-flavivirus encephalitis. IntechOpen, 2011. https://doi.org/10.5772/24967

38. Meijer WJ, Linn FH, Wensing AM, Leavis HL, van Riel D, GeurtsvanKessel $\mathrm{CH}$, et al. Acute influenza virus-associated encephalitis and encephalopathy in adults: a challenging diagnosis. JMM Case Rep 2016; 3(6): e005076. https://doi.org/10.1099/jmmcr.0.005076

39. Bohmwald K, Gálvez NMS, Ríos M, Kalergis AM. Neurologic alterations due to respiratory virus infections. Front Cell Neurosci 2018; 12: 386. https://doi.org/10.3389/ fncel.2018.00386
40. Hazleton JE, Berman JW, Eugenin EA. Novel mechanisms of central nervous system damage in HIV infection. HIV AIDS (Auckl) 2010; 2: 39-49. https://doi.org/10.2147/ HIV.S9186

41. Netland J, Meyerholz DK, Moore S, Cassell M, Perlman S. Severe acute respiratory syndrome coronavirus infection causes neuronal death in the absence of encephalitis in mice transgenic for human ACE2. J Virol 2008; 82(15): 7264-75. https://doi.org/10.1128/JVI.00737-08

42. Dube M, Le Coupanec A, Wong AHM, Rini JM, Desforges M, Talbot PJ. Axonal transport enables neuron-to-neuron propagation of human coronavirus OC43. J Virol 2018; 92(17): e00404-18. https://doi.org/10.1128/ JVI.00404-18

43. Perlman S, Evans G, Afifi A. Effect of olfactory bulb ablation on spread of a neurotropic coronavirus into the mouse brain. J Exp Med 1990; 172(4): 1127-32. https://doi.org/10.1084/ jem.172.4.1127

44. Needham EJ, Chou SH, Coles AJ, Menon DK. Neurological implications of COVID-19 infections. Neurocrit Care 2020; 32: 667-71. https://doi.org/10.1007/s12028-020-00978-4

\section{A. Jasionis, R. Mameniškienė \\ COVID-19: NEUROLOGICAL SYMPTOMS AND ENCEPHALITIS}

\section{Summary}

In the height of COVID-19 pandemic, there is growing amount of data on neurological manifestations of the disease. They can be caused by a serious medical condition, acute neurological injuries or exacerbation of chronic neurological disorders, and adverse effects of antiviral therapies. Moreover, first reports of suspected encephalitis cases also appear. This article discusses published data on neurological manifestations of COVID-19 and their possible explanation, and presents reported encephalitis cases. Brain injury caused by other coronaviruses is also examined. Finally, we discuss the possible mechanisms by which the virus can enter the brain and cause injury.

Keywords: COVID-19 encephalitis, SARS-CoV-2, coronaviruses, encephalitis.

Gauta:

20200501

Priimta spaudai: 20200606 